\title{
Guns, Germs, and Steel by Jared Diamond
}

\author{
Joseph Fail Jr.
}

Published online: 12 February 2008

(C) Springer Science + Business Media, LLC 2008

Can the scope of a historical novel be too broad? This question goes to the heart of the reader's ability to follow the comprehensive world history and ecology lessons contained in Guns, Germs, and Steel by Jared Diamond. While the basic story is simple and easy for the lay reader to comprehend, the intricacies of it are more troublesome, and - very especially so after reading the author's afterword in the 2003 edition - one wonders if the central lessons of the book could have been taught more crisply than the 400+ pages the author thought it required. 'My main conclusion (of Guns, Germs, and Steel) was that societies developed differently on different continents because of differences in continental environments, not in human biology.' Ah, so crisply well put. Does it take 400 pages to stress and restress this point? I suppose, from a historical point of view, yes, but for us non-historians - in this case one interested in ecology and evolution - the answer is perhaps not.

The book starts by stating Yali's Question: 'Why is it that you white people developed so much cargo and brought it to New Guinea, but we black people had little cargo of our own?' Diamond uses 400 pages to answer this provocative question - one, by the way, which is central to studies of human impacts on environments, i.e. ecology. He essentially sets up a race between cultures - asking questions like, 'Why did the Inca emperor not capture Charles I of Spain...' rather than the reverse? He sets geography as the dominant factor in the answers to such questions, routinely emphasizing that it is not race/genes that determine human history but rather the environmental

\section{J. Fail Jr. $(\square)$}

Department of Natural Sciences,

Johnson C. Smith University,

Charlotte, NC, USA

e-mail: jfail@jcsu.edu context where the genes we do have are placed. This is a perfect introduction to Evolution 101.

This discussion leads to consideration of how the geographic location and timing of the development of agriculture provides the boost needed for some cultures to overcome and dominate others. Germs follow from - and because of - agriculture, and especially in places (Old World) where domesticable animal genes (cows, horses) are located. Inevitably, these cultural evolutions lead to writing, then technology, thence to governments that evolve to best control the various evolved technologies of humans. (Many of the ideas related in these sections were also presented in a classic paper in Science by Lynn White, Jr. in 1967, 'The Historical Roots of Our Ecologic Crisis' that the reviewer highly recommends as required reading in ecology classes).

The role of evolution, both culturally (e.g. artificial selection) and naturally, is discussed clearly at numerous places throughout the book. Diamond teaches us about the processes by providing examples in which he outlines the forces at play and lets us fill in the gaps. His exquisite teaching is well demonstrated in his discussion of "The Lethal Gift of Livestock". Diamond states, "Basically, microbes evolve like other species. Evolution selects for those individuals most effective at producing babies and at helping them spread to suitable places to live. For a microbe, spread may be defined mathematically as the number of new victims infected per each original patient. That number depends on how long each victim remains capable of infecting new victims and how efficiently the microbe is transferred from one victim to the next.... The germ that spreads better leaves more babies and ends up favored by natural selection. Many of our 'symptoms' of disease actually represent ways in which some damned clever microbe modifies our bodies or our behavior such that we become enlisted to spread microbes" (p. 198). This is the 
kind of teaching that students at many levels - including scientists - can learn much from. Diamond thus provides an example of evolutionary mechanisms that we can relate to and readily understand. The author is talking with us, not to us, and the reader has a sense of two-way conversation where we are expected to think our way through gaps in the story, rather than be led by an all-knowing seer.

Perhaps because I teach at Historically Black Colleges and Universities (HBCU), I was especially intrigued by the last chapter in the book-'How Africa Became Black'. Diamond provides the answers to this puzzle through analysis of the history of African languages and connecting those evidences to his previous lessons and to his theories (let us not forget) that cultures (Bantu in central and southern Africa) that solved problems of domesticated food production also produced “...germs, technology, political organization, and other ingredients of power. Peoples who, by accident of their geographic location, inherited or developed food production thereby became able to engulf geographically less endowed people" (p.386). He links this agricultural conquest to both human migration and geography, showing that inevitably, the cultures with food-production technology and the means to protect it were ultimately politically and culturally victorious. Race, Diamond drives home again, was and is irrelevant.

Students of ecology must become aware of the impact of our human footprint on nature, and Diamond's book provides an excellent avenue to explore that footprint. My solution to the dilemma of teaching this wideranging and far-reaching book - of including it seamlessly into a story of ecology - has been to work with select chapters/sections and discuss their lessons in class. So, for example, in my class, I state Yali's Question and follow it with a lesson on world geography (this book provides an excellent avenue for its inclusion into an ecology curriculum, and all ecology teachers will likely agree that student knowledge of geography is generally abysmal), then reading and discussing "The Lethal Gift of Livestock-The Evolution of Germs", noting along with its discussion, select parts of "Farmer Power-The Roots of Guns, Germs, and Steel". I end our lessons on the book with a discussion of "How Africa Became Black". This last chapter sums up much of the previous lessons taught in the book and also is a topic to which students at HBCUs can relate.

This essential ecological history lesson with its routine reminders of the role of evolution in human endeavor can thus be incorporated into ecology curricula fairly easily and straightforwardly and can make a lasting impression on student perceptions of our human impacts on the environment and also its reverse - the effects of environment on human progress. Those topics are explored by Dr. Diamond in his next book, Collapse. 